\title{
PREDIKTOR TERKUAT TINGGINYA DUKUNGAN KELUARGA PADA PENDERITA ULKUS DIABETIKUM
}

\author{
Ni Putu Wulan Purnama Sari', Maria Manungkalit ${ }^{2}$ \\ Fakultas Keperawatan Universitas Katolik Widya Mandala Surabaya \\ J1. Kalisari Selatan 1, Pakuwon City, Surabaya, Indonesia \\ wulanpurnama@ukwms.ac.id
}

\begin{abstract}
Abstrak
Diabetes Mellitus (DM) memiliki komplikasi mikroangiopati, salah satunya adalah neuropati diabetik dengan gejala hilangnya sensasi daerah ekstrimitas bawah yang merupakan faktor risiko terpenting dari terjadinya ulkus diabetikum. Dukungan keluarga diperlukan para penderita ulkus diabetikum untuk dapat mengelola penyakitnya dengan baik selama masa rawat rumah. Penelitian ini bertujuan mengidentifikasi dan menganalisis tingkat dukungan keluarga dan prediktor terbaik dari dukungan keluarga yang tinggi pada penderita DM tipe 2 dengan ulkus diabetikum. Penelitian deskriptif korelatif ini menggunakan cross sectional design. Populasi adalah seluruh penderita DM tipe 2 dengan ulkus diabetikum di Rumah Luka Surabaya di Sidoarjo berjumlah 100 orang $(\mathrm{N}=100)$. Tehnik sampling Total sampling $(\mathrm{n}=100)$. Variabel dalam penelitian ini adalah dukungan keluarga yang terdiri dari empat domain, yaitu: dukungan emosional, instrumental, informasional, dan penghargaan. Kuesioner yang valid dan reliabel. Mayoritas responden mendapatkan dukungan yang tinggi dari keluarganya (97\%). Di antara empat domain dukungan keluarga, dukungan informasional merupakan domain yang menjadi prediktor terkuat dari tingginya dukungan keluarga pada populasi ini (item 18: $\mathrm{R}^{2}=0.529 ; \mathrm{p}$ $=0.000 ;$ item 19: $\mathrm{R}^{2}=0.531 ; \mathrm{p}=0.000$ ). Namun, aspek penghargaan atas usaha penderita untuk mengobati penyakitnya menjadi prediktor terkuat dari tingginya dukungan keluarga secara keseluruhan (item 24: $\mathrm{R}^{2}=0.616 ; \mathrm{p}=0.000$ ). Dukungan informasional dan penghargaan atas usaha untuk mengelola penyakit menjadi dua prediktor penting dari tingginya dukungan keluarga pada penderita ulkus diabetikum.
\end{abstract}

Kata kunci : Diabetes Mellitus, dukungan informasional, dukungan keluarga, dukungan penghargaan, ulkus diabetikum.

\begin{abstract}
Diabetes Mellitus (DM) has micro-angiopathic complications, one of which is diabetic neuropathy with symptoms of loss of sensation in the lower extremity area which is the most important risk factor for diabetic ulcers. Family support is needed for diabetic ulcer sufferers to be able to manage their disease well during the home care period. This study aims to identify and analyze the level of family support and the best predictor of high family support in type 2 DM patients with diabetic ulcers. This descriptive correlative research used a cross sectional design. The population was all patients with type 2 DM with diabetic ulcers at the Surabaya Wound House in Sidoarjo amounted to 100 people $(N=100)$. Sampling technique total sampling $(n=100)$. The variable was family support which consisted of four domains, namely: emotional, instrumental, informational, and appraisal supports. Valid and reliable questionnaire was used during data collection. The majority of respondents got high support from their family (97\%). Among the four domains of family support, informational support is the domain being the strongest predictor of high family support in this population (item 18: $\mathrm{R}^{2}=0.529 ; \mathrm{p}=0.000 ;$ item $\left.19: \mathrm{R}^{2}=0.531 ; \mathrm{p}=0.000\right)$. However, the aspect of appreciation for the sufferer's efforts to treat their illness becomes the strongest predictor of the high overall family support (item 24: $R^{2}=0.616 ; p=0.000$ ). Informational support and appreciation for efforts to manage the disease are two important predictors of high family support in diabetic ulcer sufferers.
\end{abstract}

Keywords: Diabetes Mellitus, informational support, family support, appraisal support, diabetic ulcer.

Corresponding author:

Ni Putu Wulan Purnama Sari

wulanpurnama@ukwms.ac.id 


\section{PENDAHULUAN}

Diabetes mellitus (DM) memiliki komplikasi makroangiopati dan mikroangiopati yang bersifat menahun. Makroangiopati akan menyebabkan gangguan pada pembuluh darah besar, pembuluh darah otak, dan pembuluh darah tepi sedangkan pada mikroangiopati akan menyebabkan gangguan pada retinopati diabetik, nefropati diabetik, dan neuropati. Salah satu gejala yang terjadi ketika sesorang mengalami diabetes neuropati adalah hilangnya sensasi daerah ektermitas bawah dan merupakan faktor terpenting yang beresiko tinggi terjadinya ulkus diabetikum yang meningkatkan resiko amputasi (Perkeni, 2015). Ulkus diabetikum merupakan salah satu dari komplikasi kronis DM yang ditandai dengan adanya luka terbuka yang timbul secara spontan akibat dari trauma dan mampu menghasilkan gas gangren yang menyebabkan terjadinya osteomielitis (Kartika, 2017). Ulkus diabetikum dapat menyebabkan komplikasi kardiovaskular baik secara makro maupun mikro. Komplikasi makrovaskular akan didapati adanya resistensi insulin sedangkan komplikasi mikrovaskular lebih dikarenakan adanya hiperglikemia kronik.

Berdasarkan data World Health Organization (WHO), di Indonesia angka penderita DM mengalami kenaikan jumlah dari 8,4 juta pada tahun 2000 menjadi sekitar 21,3 juta pada tahun 2030 (Decroli, 2019). Indonesia juga menempati urutan ke-7 dengan penderita diabetes terbesar diseluruh dunia (Kemenkes RI, 2016). Meningkatnya jumlah penderita diabetes maka akan sejalan peningkatannya dengan kejadian ulkus diabetikum terutama pada ulkus kaki diabetik. DM dengan komplikasi ulkus diabetik menempati peringkat ke-6 dari sepuluh penyakit utama pada pasien rawat jalan dan rawat inap di rumah sakit Indonesia dengan angka kematian akibat ulkus berkisar 17-23\%, angka amputasi berkisar 15$30 \%$ dan angka kematian satu tahun post amputasi sebesar 14,8\% (Kemenkes RI, 2012). Penelitian yang dilakukan oleh Farida, Arini, \& Mardayati, (2018) hasil yang didapatkan menunjukkan angka kejadian ulkus kaki diabetik di rumah rawat luka di Surabaya pada tahun 2016 didapatkan kurang lebih 10-15 pasien perbulan yang dirawat karena menderita ulkus kaki diabetikdengan derajat 3-4. Survei awal yang dilakukan didapati jumlah pasien yang melakukan perawatan luka di Rumah
Luka Surabaya di Sidoarjo pada bulan Maret 2020 sejumlah 40 orang.

Ulkus diabetikum terjadi beberapa perubahan fisiologis yang diinduksi oleh hiperglikemia jaringan ekstremitas bawah. Sistem saraf dirusak oleh keadaan hiperglikemia melalui berbagai cara sehingga memudahkan terjadinya cidera pada saraf motorik, sensorik, dan otonom. Pada saraf motorik akan terjadi kelemahan otot, atropi dan paresis. Pada saraf sensorik akan terjadi hilangnya sensasi nyeri, tekanan, dan panas yang protektif. Pada saraf otonom akan terjadi vasodilatasi dan pengurangan keringat yang menyebabkan hilangnya integritas kulit, yang membentuk lokasi ideal untuk invasi mikrobial (Kartika, 2017).

Dukungan keluarga pada pasien dengan ulkus diabetikum dibutuhkan pasien dalam perawatan luka dan pengobatan karena kedua penatalaksanaan tersebut membutuhkan waktu yang lama. Keluarga diharapkan dapat berperan dalam upaya meningkatkan status kesehatan pasien dan membantu mengurangi beban fisik dan emosional. Kaplan \& Saddock (2014) menyatakan bahwa dukungan psikososial keluarga merupakan suatu mekanisme hubungan interpersonal yang dapat melindungi sesorang dari efek stres yang buruk. Menurut Friedman, Bowden, \& Jones (2014) menyatakan bawa fungsi afektif keluarga merupakan dukungan psikososial keluarga kepada anggotanya sehingga anggota keluarga tersebut merasa nyaman dan dicintai akan tetapi bila fungsi ini tidak adekuat maka individu akan merasa diasingkan dan tidak diharapkan oleh keluarga. Terutama pada pasien dengan DM ulkus diabetikum yang membutuhan pengobatan dan perawatan luka dalam waktu yang lama, maka dukungan keluarga tersebut dibutukan dalam pendampingan penatalaksanaan pengobatan dan perawatannya. Penelitian ini bertujuan mengidentifikasi dan menganalisis tingkat dukungan keluarga dan prediktor terbaik dari dukungan keluarga yang tinggi pada penderita DM tipe 2 dengan ulkus diabetikum.

\section{METODE PENELITIAN}

Penelitian ini merupakan jenis penelitian deskriptif korelatif dengan pendekatan cross sectional design. Populasi adalah seluruh penderita DM tipe 2 dengan ulkus diabetikum di Rumah Luka Surabaya di Sidoarjo berjumlah 
100 orang $(\mathrm{N}=100)$. Teknik pemilihan sampel total sampling diterapkan dalam penelitian ini. Sampel dalam penelitian ini adalah seluruh anggota populasi $(n=100)$.

Variabel dalam penelitian ini adalah dukungan keluarga. Definisi operasional variabel yang digunakan dalam penelitian ini adalah suatu sikap atau tindakan berupa dukungan dalam bentuk emosional, instrumental, dukungan informasi, dukungan penghargaan yang terbentuk karena adanya hubungan interpersonal antara keluarga dengan responden. Dukungan keluarga diukur menggunakan instrumen berupa kuesioner yang disusun oleh Putri (2020). Kuesioner ini terdiri dari 24 item yang tersebar dalam empat domain dukungan keluarga, yaitu: 1) dukungan instrumental (7 item), 2) dukungan informasional (6 item), 3) dukungan emosional (7 item), dan 4) dukungan penghargaan (4 item). Rentang respon dalam skala Likert 1-4 digunakan untuk membedakan respon responden. Dukungan keluarga dibedakan menjadi tiga tingkatan, yaitu: 1) dukungan keluarga tinggi (total skor: 73-96), 2) dukungan keluarga cukup (total skor: 49-72, dan 3) dukungan keluarga rendah (total skor: 24-48). Uji coba terpakai dilakukan untuk mengevaluasi validitas dan reliabilitas dari instrumen penelitian. Hasil uji coba terpakai terhadap 100 orang responden menunjukkan bahwa kuesioner dukungan keluarga valid $(\mathrm{r}=$ 0,529-0,727) dan reliabel (Chronbach Alpha $=$ 0,889 ).

Pengumpulan data dilakukan pada bulan Maret-Juni 2021 di Rumah Luka Surabaya di Sidoarjo. Aspek etika penelitian yang diterapkan meliputi penerapan prinsip manfaat, menghargai hak asasi manusia, keadilan, hak untuk dijaga kerahasiaannya, dan informed consent. Setelah data penelitian terkumpul maka dilakukan analisis data melalui tahapan editing, scoring, coding, tabulating, dan uji hipotesis menggunakan statistika deskriptif (frequency, Mean, dan standard deviasi/SD) dan uji regresi linear.

\section{HASIL}

Hasil penelitian menunjukkan mayoritas responden berusia 46-55 tahun, perempuan, lulusan SD, menikah, menderita DM selama 15 tahun, menderita ulkus diabetikum kurang dari setahun, paling sering dirawat anak di rumah, paling dekat dengan pasangan dan anak, rutin melakukan perawatan luka sebanyak 1 atau 3 kali seminggu. Tabel 1 menjelaskan secara detil karakteristik demografi responden penelitian.

Tabel 1

Karakteristik Demografi Responden

\begin{tabular}{clcc}
\hline No. & \multicolumn{1}{c}{ Karakteristik } & Frekuensi (F) & Persentase (\%) \\
\hline 1 & Usia: & 2 & \\
& Dewasa awal (26-35 tahun) & 12 & 12 \\
& Dewasa akhir (36-45 tahun) & 39 & 39 \\
& Lansia awal (46-55 tahun) & 37 & 37 \\
& Lansia akhir (56-65 tahun) & 10 & 10 \\
& Manula (lebih dari 65 tahun) & & \\
2 & Jenis kelamin: & 42 & 42 \\
& Laki-laki & 58 & 58 \\
Perempuan & & 39 \\
Tingkat pendidikan: & 39 & 18 \\
& SD & 18 & 31 \\
& SMP & 31 & 12 \\
& SMA & 12 & 77 \\
& Perguruan tinggi & & 23 \\
Status pernikahan: & 77 & 32 \\
Menikah & 23 & 31 \\
5anda/duda & & 33 \\
& Orang terdekat: & 32 & \\
& Pasangan & 31 & \\
& Anak & 33 &
\end{tabular}




\begin{tabular}{|c|c|c|c|}
\hline & Lain-lain & 4 & 4 \\
\hline \multirow[t]{5}{*}{6} & Keluarga yang merawat: & & \\
\hline & Pasangan & 48 & 48 \\
\hline & Anak & 55 & 55 \\
\hline & Tidak ada & 5 & 5 \\
\hline & Lain-lain & 2 & 2 \\
\hline \multirow[t]{5}{*}{7} & Lama menderita DM: & & \\
\hline & Kurang dari setahun & 23 & 23 \\
\hline & $1-5$ tahun & 44 & 44 \\
\hline & 6-10 tahun & 14 & 14 \\
\hline & Lebih dari 10 tahun & 19 & 19 \\
\hline \multirow[t]{4}{*}{8} & Lama menderita ulkus diabetikum: & & \\
\hline & Kurang dari setahun & 56 & 56 \\
\hline & $1-5$ tahun & 38 & 38 \\
\hline & 6-10 tahun & 6 & 6 \\
\hline \multirow[t]{3}{*}{9} & Rutinitas perawatan luka: & & \\
\hline & Rutin & 90 & 90 \\
\hline & Tidak rutin & 10 & 10 \\
\hline \multirow[t]{4}{*}{10} & Frekuensi perawatan luka: & & \\
\hline & 1 kali seminggu & 38 & 38 \\
\hline & 2 kali seminggu & 24 & 24 \\
\hline & 3 kali seminggu & 38 & 38 \\
\hline
\end{tabular}

Hasil penelitian juga menunjukkan rendah (0\%). Bahkan yang menerima dukungan mayoritas responden menerima dukungan keluarga cukup sangat minimal (3\%). Tabel 2 keluarga yang tinggi (97\%). Tidak ada satupun menjelaskan secara detil tingkat dukungan responden menerima dukungan keluarga yang keluarga yang diterima responden.

Tabel 2

Dukungan Keluarga

\begin{tabular}{clccc}
\hline No. & & Karakteristik & Frekuensi (F) & Persentase (\%) \\
\hline 1 & Tinggi & 97 & 97 \\
2 & Cukup & 3 & 3 \\
3 & Rendah & 0 & 0
\end{tabular}

Hasil uji hipotesis terhadap responden memberitahukan kondisi Bapak/Ibu yang yang menerima dukungan keluarga yang tinggi $(\mathrm{n}=97)$ menunjukkan bahwa prediktor terkuat dari tingginya dukungan keluarga yang diterima oleh penderita DM tipe 2 dengan ulkus diabetikum adalah item 24 tentang "keluarga tidak menghargai usaha yang Bapak/Ibu lakukan dalam pengobatan" yang berada pada domain dukungan penghargaan $\left(\mathrm{R}^{2}=0.616 ; \mathrm{p}=\right.$ 0.000). Selain itu item 19 dan 18 tentang "keluarga memberikan saran-saran yang membosankan untuk menjaga kondisi kesehatan Bapak/Ibu" $\left(\mathrm{R}^{2}=0.531 ; \mathrm{p}=0.000\right)$ dan "keluarga merahasiakan dan tidak sebenarnya sesuai dari penjelasan dokter" $\left(\mathrm{R}^{2}=\right.$ $0.529 ; \mathrm{p}=0.000$ ) yang berada pada domain dukungan informasional juga merupakan prediktor yang kuat yang berada di urutan kedua dan ketiga setelah item 24. Secara dimensional, domain dukungan informasional memiliki pengaruh yang lebih kuat terhadap variabel dukungan keluarga jika dibandingkan dengan domain dukungan penghargaan karena terdapat dua prediktor kuat di dalamnya. Namun, tidak ada item di dalam domain dukungan penghargaan yang tidak menjadi prediktor dukungan keluarga. 
Tabel 3

Prediktor Dukungan Keluarga Tinggi

\begin{tabular}{|c|c|c|c|c|}
\hline $\begin{array}{l}\text { No. } \\
\text { Item }\end{array}$ & Pernyataan & Nilai $\mathbf{R}^{2}$ & $\begin{array}{c}\text { Besar } \\
\text { Pengaruh }\end{array}$ & Nilai p \\
\hline \multicolumn{5}{|c|}{ Dukungan Emosional } \\
\hline 1 & Keluarga memberikan perhatian kepada Bapak/Ibu selama sakit & 0.019 & $-\overline{---}$ & 0.174 \\
\hline 2 & Keluarga tetap mencintai Bapak/Ibu dalam keadaan sakit & 0.026 & --- & 0.106 \\
\hline 3 & $\begin{array}{l}\text { Keluarga percaya penyakit yang di derita Bapak/ Ibu adalah } \\
\text { kehendak Tuhan dan akan sembuh }\end{array}$ & 0.010 & --- & 0.323 \\
\hline 4 & $\begin{array}{l}\text { Keluarga peduli dengan keadaan atau keluhan yang Bapak/Ibu } \\
\text { rasakan selama sakit }\end{array}$ & 0.026 & --- & 0.106 \\
\hline 5 & $\begin{array}{l}\text { Keluarga tidak memperdulikan keadaan dan keluhan Bapak/Ibu } \\
\text { selama sakit }\end{array}$ & 0.396 & $39.6 \%$ & 0.000 \\
\hline 6 & $\begin{array}{l}\text { Keluarga tidak peduli atau mengabaikan penderitaan Bapak/Ibu } \\
\text { selama sakit }\end{array}$ & 0.416 & $41.6 \%$ & 0.000 \\
\hline 7 & $\begin{array}{l}\text { Keluarga kurang memberikan perhatian kepada Bapak/Ibu } \\
\text { selama sakit }\end{array}$ & 0.323 & $32.3 \%$ & 0.000 \\
\hline \multicolumn{5}{|c|}{ Dukungan Instrumental } \\
\hline 8 & Keluarga merawat Bapak/Ibu selama sakit & 0.002 & --- & 0.697 \\
\hline 9 & $\begin{array}{l}\text { Keluarga menyediakan waktu untuk mendampingi Bapak/Ibu } \\
\text { dalam berobat }\end{array}$ & 0.047 & $4.7 \%$ & 0.030 \\
\hline 10 & $\begin{array}{l}\text { Keluarga membawa Bapak/Ibu berobat ke fasilitas kesehatan } \\
\text { saat kondisi menurun }\end{array}$ & 0.010 & --- & 0.323 \\
\hline 11 & $\begin{array}{l}\text { Keluarga bersedia membiayai perawatan dan pengobatan } \\
\text { Bapak/Ibu }\end{array}$ & 0.003 & --- & 0.597 \\
\hline 12 & $\begin{array}{l}\text { Keluarga tidak membawa Bapak/Ibu ke fasilitas kesehatan untuk } \\
\text { berobat }\end{array}$ & 0.447 & $44.7 \%$ & 0.000 \\
\hline 13 & $\begin{array}{l}\text { Keluarga tidak ada waktu untuk mendampingi Bapak/Ibu dalam } \\
\text { berobat }\end{array}$ & 0.392 & 39.2 & 0.000 \\
\hline 14 & Keluarga tidak membiayai perawatan Bapak/Ibu selama sakit & 0.327 & $32.7 \%$ & 0.000 \\
\hline \multicolumn{5}{|c|}{ Dukungan informasional } \\
\hline 15 & $\begin{array}{l}\text { Keluarga memberikan nasehat mengenai hal-hal yang dapat } \\
\text { memperburuk penyakit Bapak/Ibu }\end{array}$ & 0.000 & --- & 0.830 \\
\hline 16 & $\begin{array}{l}\text { Keluarga memberikan saran kepada Bapak/Ibu bahwa } \\
\text { pentingnya melakukan aktivitas sehari-hari seperti mandi, } \\
\text { berolahraga dan aktivitas lainnya }\end{array}$ & 0.035 & --- & 0.064 \\
\hline 17 & $\begin{array}{l}\text { Keluarga memberitahu penjelasan dari dokter mengenai } \\
\text { perkemangan kondisi kesehatan Bapak/Ibu }\end{array}$ & 0.023 & --- & 0.133 \\
\hline 18 & $\begin{array}{l}\text { Keluarga merahasiakan dan tidak memberitahukan kondisi } \\
\text { Bapak/Ibu yang sebenarnya sesuai dari penjelasan dokter }\end{array}$ & 0.529 & $\mathbf{5 2 . 9 \%}$ & 0.000 \\
\hline 19 & $\begin{array}{l}\text { Keluarga memberikan saran-saran yang membosankan } \\
\text { untuk menjaga kondisi kesehatan Bapak/Ibu }\end{array}$ & 0.531 & $\mathbf{5 3 . 1 \%}$ & 0.000 \\
\hline 20 & $\begin{array}{l}\text { Keluarga memberikan nasehat yang bertentangan dengan } \\
\text { keinginan Bapak/Ibu }\end{array}$ & 0.392 & $39.2 \%$ & 0.000 \\
\hline \multicolumn{5}{|c|}{ Dukungan penghargaan } \\
\hline 21 & $\begin{array}{l}\text { Keluarga memberikan pujian atas keinginan Bapak/Ibu untuk } \\
\text { sembuh }\end{array}$ & 0.283 & $28.3 \%$ & 0.000 \\
\hline 22 & $\begin{array}{l}\text { Keluarga menghargai usaha-usaha yang Bapak/Ibu lakukan } \\
\text { dalam pengobatan }\end{array}$ & 0.283 & $28.3 \%$ & 0.000 \\
\hline 23 & $\begin{array}{l}\text { Keluarga memberikan penilaian kurang baik atas keinginan } \\
\text { Bapak/Ibu untuk sembuh }\end{array}$ & 0.476 & $47.6 \%$ & 0.000 \\
\hline 24 & $\begin{array}{l}\text { Keluarga tidak menghargai usaha yang Bapak/Ibu lakukan } \\
\text { dalam pengobatan }\end{array}$ & 0.616 & $61.6 \%$ & 0.000 \\
\hline
\end{tabular}

Tabel 3 menjelaskan hasil pengujian statistik dari setiap item dalam kuesioner dukungan keluarga untuk mendeteksi prediktor terkuat dari total skor dukungan keluarga yang dihasilkan. 


\section{PEMBAHASAN}

Dukungan keluarga merupakan suatu bentuk tindakan atau bantuan secara emosional, spiritual, instrumental yang diberikan oleh keluarga besar khususnya kerabat sekunder ((Friedman, Bowden, \& Jones, 2014). Dukungan keluarga juga didefinisikan sebagai bentuk hubungan interpersonal sikap, tindakan penerimaan keluarga terhadap anggota keluarganya, berupa dukungan informasional, dukungan penilaian, dukungan instrumental dan dukungan emosional untuk melindungi anggota keluarga yang sakit agar tidak terpuruk dan tetap semangat menghadapi penyakitnya (Witdiawati, Rahayuwati, \& Sari, 2018). Dengan demikian dapat disimpulkan bahwa dukungan keluarga adalah suatu bentuk sikap atau tindakan berupa dukungan dalam bentuk informasi, spiritual, nilai, instrumen, atau sumber daya dan emosional yang terbentuk karena adanya hubungan interpersonal antar anggota keluarga.

Dukungan keluarga dapat dikategorikan menjadi empat tipe menurut Friedman, Bowden, \& Jones (2014), yaitu: 1) dukungan emosional meliputi sarat empati, cinta, kepercayaan, dan kepedulian dari keluarga; 2) dukungan instrumental meliputi bantuan dalam merawat anggota keluarga yang sakit, menyediakan waktu, mengantar anggota keluarga ke fasilitas kesehatan, memberikan bantuan atau membiayai kebutuhan anggota keluarga yang sakit; 3) dukungan informasional meliputi nasehat, saran, dan informasi yang berguna untuk memecahkan masalah identitas diri; dan 4) dukungan penghargaan meliputi pujian atau penghargaan yang diberikan keluarga terhadap anggota keluarga yang sakit.

Hasil penelitian menunjukkan mayoritas responden mendapatkan dukungan keluarga yang tinggi (97\%). Perlu disyukuri bahwa tidak ada responden yang melapor mendapat dukungan keluarga yang rendah di dalam penelitian ini. Hasil penelitian ini didukung oleh penelitian Ruslan (2016) terhadap 30 orang penderita ulkus diabetikum yang juga menemukan mayoritas dukungan keluarga tinggi (47\%). Setiadi (2008) berpendapat bahwa dukungan keluarga dipengaruhi oleh dua faktor, yaitu faktor internal dan eksternal. Faktor internal meliputi tahap perkembangan, pendidikan atau pengetahuan, kondisi emosional, dan spiritual. Faktor eksternal meliputi faktor sosial ekonomi dan latar belakang budaya. Friedman, Bowden, \& Jones (2014) berpendapat bahwa dukungan keluarga dipengaruhi oleh faktor sosial ekonomi, pendapatan atau pekerjaan anggota keluarga, dan tingkat pendidikan.

Di dalam penelitian ini, karakteristik demografi dari keluarga responden tidak dikaji. Pengukuran dukungan keluarga yang dilakukan dalam penelitian ini dipersepsikan secara subjektif oleh responden penelitian, yaitu penderita ulkus diabetikum itu sendiri. Berdasarkan hasil obsrevasi peneliti, bentuk dukungan keluarga yang tampak nyata selama proses perawatan luka di lokasi penelitian adalah: 1) dukungan instrumental: keluarga mengantar responden ke lokasi penelitian dengan mobil atau sepeda motor, keluarga membayar biaya perawatan luka, dan keluarga membelikan obat yang diperlukan, 2) dukungan informasional: keluarga memberi tahu bahwa ada klinik khusus untuk tempat rawat luka, dan keluarga mencarikan informasi kesehatan yang dibutuhkan oleh responden secara daring maupun luring, 3) dukungan emosional: keluarga menepati jadwal kontrol rutin ke rumah luka, keluarga memantau perkembangan kesembuhan luka, keluarga selalu mendampingi responden saat lukanya sedang dirawat, dan 4) dukungan penghargaan: keluarga mengekspresikan secara verbal bahwa responden dengan senang hati bersedia dirawat lukanya di lokasi penelitian, dan keluarga membesarkan hati responden dengan memberikan apresiasi yang baik pasca perawatan luka.

Hasil penelitian juga menunjukkan bahwa secara dimensional dukungan informasional memiliki pengaruh yang paling kuat terhadap tingginya dukungan keluarga jika dibandingkan dengan tiga domain lainnya. Mayoritas responden melaporkan bahwa keluarga tidak pernah merahasiakan kondisi kesehatan yang sebenarnya dan sudah sesuai dengan penjelasan dokter (86\%) dan tidak pernah memberi saran yang membosankan untuk menjaga kondisi kesehatan mereka (91\%). Dua hal ini menjadi prediktor terkuat yang berasal dari domain dukungan informasional, sehingga dua hal ini menjadi alasan mengapa dukungan informasional menjadi prediktor terkuat secara dimensional. Dukungan informasional adalah dukungan untuk mengatasi masalah personal atau environmental pada kondisi stres melalui 
penyediaan informasi yang relevan dan cukup (Palaya, et al., 2018). Dukungan informasional ini menjadi salah satu aspek dari dukungan fungsional yang sangat diperlukan dalam perawatan sehari-hari penderita ulkus diabetikum di rumah oleh keluarganya (Lee, et al., 2019). Dukungan informasional memiliki korelasi signifikan dengan perilaku self care pada pasien ulkus diabetik (Putri \& Bahri, 2016). Dukungan yang diberikan oleh keluarga dan lingkungan dalam berbagai cara seperti informasi yang diberikan oleh keluarga berdampak pada perubahan perilaku penderita luka kaki diabetik (Nurmansyah, et al., 2018). Dengan demikian keluarga berperan menjadi pendukung kesehatan informal yang memberikan dukungan otonomi kepada penderita ulkus diabetikum dalam proses perawatannya di rumah.

Walaupun secara dimensional domain dukungan informasional memiliki pengaruh lebih besar dari domain dukungan penghargaan, namun secara keseluruhan item 24 pada domain dukungan penghargaan yang menjadi prediktor terkuat dari tingginya dukungan keluarga yang ditemukan pada penelitian ini. Mayoritas responden melaporkan keluarga selalu menghargai usaha yang mereka lakukan dalam pengobatan penyakitnya (95\%). Dukungan keluarga sangat berarti bagi pasien jika dukungannya bersifat penilaian positif (Prasetyawati, 2012). Hal ini terjadi karena dukungan penghargaan berupa penilaian yang positif dari keluarga dapat memingkatkan harga diri penderita ulkus diabetikum. Apabila ada dukungan keluarga maka rasa percaya diri penderita akan bertambah dan motivasi untuk menghadapi masalah kesehatan yang terjadi juga akan meningkat (Wibowo, 2017). Hasil penelitian ini membuktikan bahwa dukungan penghargaan yang diberikan oleh keluarga atas usaha penderita ulkus diabetikum utuk mengelola penyakitnya secara mandiri adalah sangat bermakna.

\section{KESIMPULAN}

Mayoritas penderita ulkus diabetikum mendapatkan dukungan yang tinggi dari keluarganya. Di antara empat domain dukungan keluarga, dukungan informasional merupakan domain yang menjadi prediktor terkuat dari tingginya dukunga keluarga pada populasi ini. Alasannya, karena keluarga tidak pernah merahasiakan kondisi kesehatan yang sebenarnya dan sudah sesuai dengan penjelasan dokter, dan tidak pernah memberi saran yang membosankan untuk menjaga kondisi kesehatan mereka. Di luar itu, aspek penghargaan atas usaha penderita untuk mengobati penyakitnya menjadi prediktor terkuat dari tingginya dukungan keluarga secara keseluruhan.

\section{DAFTAR PUSTAKA}

Decroli, E. (2019). Diabetes Mellitus Tipe 2. Padang: Pusat Penerbitan Bagian Ilmu Penyakit Dalam Fakultas Kedokteran Universitas Andalas.

Farida, I., Arini, D., \& Mardayati, R. P. (2018). Efektifitas Perawatan Luka Modern Kombinasi Mendengarkan Musik Klasik Terhadap Penyembuhan Ulkus Diabetik di Rumah Luka Surabaya. Jurnal Ilmiah Keperawatan, 13(1), 1264-1275.

Friedman, M. M., Bowden, F. R., \& Jones, E. G. (2014). Buku ajar keperawatan keluarga: Riset Teori \& Praktik (5th ed.; E. edisi bahasa I. Tiar, ed.). Jakarta: Penerbit Buku Kedokteran EGC.

Kaplan, H. I., Saddock, B. J., \& Grabb, J. A. (2014). Kaplan-Saddock Sinopsis Psikiatri Ilmu Pengetahuan Prilaku Psikiatri Klinis. Tangerang : Bina Rupa.

Kartika R. W. (2017). Pengelolaan Gangren Kaki Diabetik. Cermin Dunia Kedokteran, 44(1), 18-22.

Kemenkes RI. (2016). Infodatin Pusat Data dan Informasi Kementerian Kesehatan. Jakarta: Kementrian Kesehatan Republik Indonesia.

Kemenkes RI. (2012). Survei Kesehatan Dasar Indonesia. Jakarta: Kementrian Kesehatan Republik Indonesia.

Lee, A. A., Piette, J. D., Heisler, M., Janevic, M. R., \& Rosland, A.-M. (2019). Diabetes self-management and glycemic control: The role of autonomy support from informal health supporters. Health Psychology, 38(2), 122132. https://doi.org/10.1037/hea0000710 
Nurmansyah, A. S., Rochmawati, E., \& Primanda, Y. (2018). Pengalaman Pasien Ulkus Kaki Diabetik Terkait Dukungan Keluarga Di Klinik Kitamura Pontianak. Dinamika Kesehatan: Jurnal Kebidanan Dan Keperawatan, 9(2), 226-239.

Palaya, J., Pearson, S., \& Nash, T. (2018). Perception of social support in individuals living with a diabetic foot: A qualitative study. Diabetes Research and Clinical Practice, 146, 267-277.

PERKENI. (2015). Pengelolaan dan Pencegahan Diabetes Melitus Tipe 2 di Indonesia. Jakarta: PERKENI.

Prasetyawati, E. A. (2012). Kesehatan Ibu dan Anak (KIA) dalam Millenium Development Goals (MDGs). Yogyakarta: Nuha Medika.

Putri, S. S., \& Bahri, T. S. (2016). Dukungan Keluarga dengan Perilaku Self-Care pada Pasien Ulkus Diabetik di RSUD Dr. Zainoel Abidin. Jurnal Ilmiah
Mahasiswa Fakultas Keperawatan, 1(1), 1-7.

Ruslan D. K. (2016). Skripsi: Hubungan antara Dukungan Keluarga dengan Harga Diri pada Pasien Ulkus Diabetikum di Poliklinik Penyakit Dalam RSUD Dr. Moewardi. Surakarta: Fakultas Ilmu Kesehatan, Universitas Muhammadiyah Surakarta.

Setiadi. (2008). Konsep dan Proses Keperawatan Keluarga. Yogyakarta: Graha Ilmu.

Wibowo, T. A. (2017). Hubungan antara Dukungan Keluarga dengan Harga Diri Pasien Gagal Ginjal Kronik yang Menjalani Hemodialisis di RSUD Dr. Kanujoso Djatiwibowo Balikpapan. Jurnal Ilmu Kesehatan, 5(1), 56-60.

Witdiawati, R. L., \& Sari, S. P. (2018). Studi Ethnography-Ethnonursing: Konsep \& Aplikasi Penelitian tentang Pasien Kanker Payudara. Jawa Barat: Universitas Padjajaran Press. 